\title{
Badania możliwości współspalania biogazu rolniczego i LNG lub LPG w urządzeniach użytku domowego oraz w urządzeniach do zastosowań przemystowych
}

\begin{abstract}
Praca przedstawia wyniki badań nad możliwością spalania mieszaniny biogazu rolniczego z LNG lub LPG w urządzeniach gazowych użytku domowego oraz w urządzeniach do zastosowań przemysłowych przystosowanych do spalania gazów E i Lw bez potrzeby ich modyfikacji. Rozpatrywano trzy grupy urządzeń: wykorzystywane do przygotowania ciepłej wody użytkowej, do przygotowania gorącej wody do centralnego ogrzewania oraz do nadmuchowego ogrzewania pomieszczeń w zastosowaniach przemysłowych. Jako przedstawicieli tych grup urządzeń wybrano odpowiednio: gazowy grzejnik wody przepływowej, kocioł gazowy z zamkniętą komorą spalania z palnikiem typu pre-mix oraz gazową nagrzewnicę powietrza. Przeprowadzono badania znamionowego obciążenia cieplnego, jakości spalania oraz zapłonu, przenoszenia się i stabilności płomienia.
\end{abstract}

Słowa kluczowe: biogaz, LPG, LNG, wymienność paliw gazowych.

\section{Researching the possibility to burn a mixture of biogas and LNG or LPG in domestic and industrial gas appliances}

\begin{abstract}
The paper presents results of researching the possibility to burn a mixture of biogas and LNG or LPG in gas appliances, which are adapted to burn gases E and Lw, without changing anything in their construction. Taken into account, were three groups of gas appliances: a device used to prepare domestic hot water, a device used to prepare hot water for central heating and a device to prepare hot air for heating an industrial building. Representing these groups of selected devices were: a gas-fired instantaneous water heater for sanitary uses production, a gas boiler with a closed chamber with a burner called ,pre-mix” and non-domestic gas air heater. Nominal heat input, quality of combustion and ignition, cross-lighting and flame stability was studied.
\end{abstract}

Key words: biogas, LPG, LNG, interchangeability of gas fuels.

\section{Wstęp}

W przypadku zatłaczania biogazu do krajowej sieci dystrybucyjnej powinien on zostać oczyszczony do parametrów gazu ziemnego rozprowadzanego tą siecią. Oprócz usunięcia z biogazu związków siarki, wilgoci oraz innych zanieczyszczeń szkodliwych dla pracy urządzeń konieczne jest zatem także usuwanie $\mathrm{CO}_{2}[1,2]$. W pracy zaproponowano rozwiązanie polegające na mieszaniu wstępnie oczyszczonego biogazu rolniczego (pozbawionego związków siarki, wilgoci oraz innych zanieczyszczeń szkodliwych dla pracy urządzeń bez eliminacji $\mathrm{CO}_{2}$ ) z gazem z regazyfikacji LNG lub z gazem LPG w takich proporcjach, aby parametry powstałych mieszanin odpowiadały parametrom energetycznym gazom drugiej rodziny grupy E i Lw [3]. Tak przygotowany gaz mógłby być zatłaczany do krajowej sieci dystrybucyjnej lub na jego bazie można by tworzyć w pobliżu biogazowni rolniczych lokalne sieci gazowe. Po analizie uzyskanych wyników badań na wytypowanych urządzeniach użytku domowego (gazowy grzejnik wody przepływowej i kocioł gazowy z zamkniętą 
komorą spalania) i urządzeniach przeznaczonych do ogrzewania obiektów niemieszkalnych (gazowa nagrzewnica powietrza z wymuszoną konwekcją) można będzie ocenić, czy zaproponowane mieszanki nadają się do spalania w wytypowanych urządzeniach nominalnie przystosowanych do gazów grupy E i Lw bez potrzeby ich modyfikacji.

\section{Określenie proporcji mieszania biogazu rolniczego z LNG lub LPG}

W celu realizacji założeń niniejszej pracy określono proporcje mieszania wstępnie oczyszczonego biogazu rolniczego z gazem z regazyfikacji LNG lub z gazem LPG, aby w końcowym efekcie uzyskać gaz o parametrach energetycznych odpowiadających minimalnym wymaganiom określonym dla gazów drugiej rodziny grupy E i Lw w normie PN-C04753:2011 (tablica 1) [4].

Poczynione założenie spalania przyjętych w pracy mieszanek o minimalnych parametrach energetycznych dla poszczególnych grup gazów wynika z faktu, że takie gazy najtrudniej spalać w urządzeniach przystosowanych do danej grupy gazu.

Analizując powyższe uwarunkowania, do badań w ramach niniejszej pracy przyjęto następujące mieszanki gazowe:

- $\mathrm{B}+\mathrm{LNG}_{(\mathrm{E})}-$ mieszanka biogazu rolniczego i gazu z regazyfikacji LNG odpowiadająca minimalnym wymaganiom dla gazu drugiej rodziny grupy $\mathrm{E}$,

- $\mathrm{B}+\mathrm{LNG}_{(\mathrm{Lw})}-$ mieszanka biogazu rolniczego i gazu z regazyfikacji LNG odpowiadająca minimalnym wymaganiom dla gazu drugiej rodziny grupy Lw,

- $\mathrm{B}+\mathrm{LPG}_{(\mathrm{E})}-$ mieszanka biogazu rolniczego i gazu LPG odpowiadająca minimalnym wymaganiom dla gazu drugiej rodziny grupy $\mathrm{E}$,

- $\mathrm{B}+\mathrm{LPG}_{(\mathrm{Lw})}-$ mieszanka biogazu rolniczego i gazu LPG odpowiadająca minimalnym wymaganiom dla gazu drugiej rodziny grupy Lw.

W tablicy 2 przedstawiono skład mieszanek gazowych, którymi zasilano badane urządzenia.

Przyjęto również, że parametrami użytkowymi ze względu na zmianę jakości gazu, których zmiany w urządzeniach należy zbadać, będą:

- obciążenie cieplne przy ciśnieniu nominalnym (nominalne ciśnienie zasilania dla gazów E i Lw wynosi $20 \mathrm{hPa}$ ),

- stężenie CO w spalinach przy obciążeniu znamionowym,

- zapłon, przenoszenie się i stabilność płomienia przy zasilaniu urządzeń ciśnieniem nominalnym dla stanu zimnego i stanu gorącego urządzenia.

Tablica 1. Minimalne wymagania energetyczne dotyczące gazu ziemnego dostarczanego odbiorcom z sieci dystrybucyjnej

\begin{tabular}{|c|c|c|c|}
\hline \multirow{3}{*}{$\begin{array}{l}\text { Wielkość charakteryzująca } \\
\text { jakość gazu }\end{array}$} & \multirow{3}{*}{ Jednostka } & \multirow{2}{*}{\multicolumn{2}{|c|}{$\frac{\text { Wymagane wartości }}{\text { grupa }}$}} \\
\hline & & & \\
\hline & & Lw & $\mathrm{E}$ \\
\hline Górna liczba Wobbego & \multirow{2}{*}{$\mathrm{MJ} / \mathrm{m}^{3}$} & \multirow{2}{*}{37,5} & \multirow{2}{*}{45,0} \\
\hline - wartość minimalna ${ }^{1}$ & & & \\
\hline Ciepło spalania nie mniejsze niż & $\mathrm{MJ} / \mathrm{m}^{3}$ & $30,0^{1}$ & $34,0^{1}$ \\
\hline Wartość opałowa nie mniejsza niż & $\mathrm{MJ} / \mathrm{m}^{3}$ & $27,0^{1}$ & $31,0^{1}$ \\
\hline
\end{tabular}

${ }^{1}$ Warunki odniesienia dla procesu spalania i objętości: $T_{1}=298,15 \mathrm{~K}\left(25^{\circ} \mathrm{C}\right)$; $T_{2}=273,15 \mathrm{~K}\left(0^{\circ} \mathrm{C}\right) ; p_{1}=p_{2}=101,325 \mathrm{kPa}$.

Tablica 2. Składy gazów po zmieszaniu biogazu rolniczego i LNG oraz biogazu rolniczego i LPG odpowiadające minimalnym wymaganiom określonych dla gazów drugiej rodziny grup E i Lw [3]

\begin{tabular}{|c|c|c|c|c|c|c|}
\hline \multirow{2}{*}{ Parametr } & \multirow{3}{*}{ Jednostka } & \multicolumn{4}{c|}{ Oznaczenia gazów oraz wartość parametru } \\
\cline { 4 - 7 } & & $\mathrm{B}+\mathrm{LNG}_{(\mathrm{E})}$ & $\mathrm{B}+\mathrm{LNG}_{(\mathrm{Lw})}$ & $\mathrm{B}+\mathrm{LPG}_{(\mathrm{E})}$ & $\mathrm{B}+\mathrm{LPG}_{(\mathrm{Lw})}$ \\
\hline \multirow{4}{*}{ Skład gazu } & metan & $\%$ & 81,1 & 74,9 & 49,8 & 56,6 \\
\cline { 2 - 7 } & etan & $\%$ & 4,8 & 3,0 & - & - \\
\cline { 2 - 7 } & propan & $\%$ & 2,5 & 1,5 & 11,8 & 6,5 \\
\cline { 2 - 7 } & butan & $\%$ & - & - & 11,8 & 6,5 \\
\cline { 2 - 7 } & ditlenek węgla & $\%$ & 11,6 & 20,6 & 26,6 & 30,4 \\
\hline Ciepło spalania $H_{S}$ & $\mathrm{MJ} / \mathrm{m}^{3}$ & 38,21 & 33,46 & 47,53 & 37,80 \\
\hline Wartość opałowa $H_{i}$ & $\mathrm{MJ} / \mathrm{m}^{3}$ & 34,53 & 30,21 & 43,42 & 34,38 \\
\hline Liczba Wobbego (górna) $W_{S}$ & $\mathrm{MJ} / \mathrm{m}^{3}$ & 45,14 & 37,76 & 45,04 & 37,50 \\
\hline
\end{tabular}

Uwaga: Parametry energetyczne podano dla warunków odniesienia $0^{\circ} \mathrm{C}$ i $\mathrm{p}=1013,25 \mathrm{hPa}$. 


\section{Opis badanych urządzeń}

Pierwsza grupa to urządzenia wykorzystywane do przygotowania ciepłej wody użytkowej. Jako przedstawiciela tej grupy wybrano gazowy grzejnik wody przepływowej. $\mathrm{Z}$ rozwiązań dostępnych na rynku wybrano najbardziej rozpowszechnione urządzenie typu $\mathrm{B}$, które zasysa powietrze do spalania z pomieszczenia, w którym jest zainstalowane, zaś spaliny omywają wymiennik ciepła i odprowadzane są do komina. W tablicy 3 przedstawiono charakterystykę techniczną urządzenia. Badany model posiada obciążenie cieplne równe $18,0 \mathrm{~kW}$. W urządzeniu nie ma regulatora ciśnienia gazu, co oznacza, że wahania ciśnienia gazu w sieci mają wpływ na osiąganą wartość obciążenia cieplnego. Model wyposażono w palnik inżektorowy (kinetyczno-dyfuzyjny), do którego dopływa powietrze: pierwotne (na zasadzie podciśnienia tworzącego się wokół dyszy gazowej, z której wypływa gaz z dużą prędkością) i wtórne (na zasadzie efektu kominowego) - fotografia 1.

Urządzenie pracuje w sposób ciągły, a regulacja obciążenia cieplnego odbywa się manualnie za pomocą pokrętła zainstalowanego na obudowie urządzenia.

Tablica 3. Charakterystyka techniczna badanego gazowego grzejnika wody przepływowej

\begin{tabular}{|l|c|}
\hline Znamionowe obciążenie cieplne & $18,0 \mathrm{~kW}$ \\
\hline Rozmiar dysz gazowych: & $1,05 \mathrm{~mm}$ \\
\hline - gaz E & $1,20 \mathrm{~mm}$ \\
\hline - gaz Lw & $12 \mathrm{sztuk}$ \\
\hline Liczba dysz gazowych & brak \\
\hline Regulator ciśnienia gazu & $\begin{array}{c}\text { inżektorowy palnik } \\
\text { kinetyczno-dyfuzyjny }\end{array}$ \\
\hline Typ palnika & ciągły \\
\hline Tryb pracy & ustawiane manualnie \\
\hline Regulacja obciążenia cieplnego &
\end{tabular}
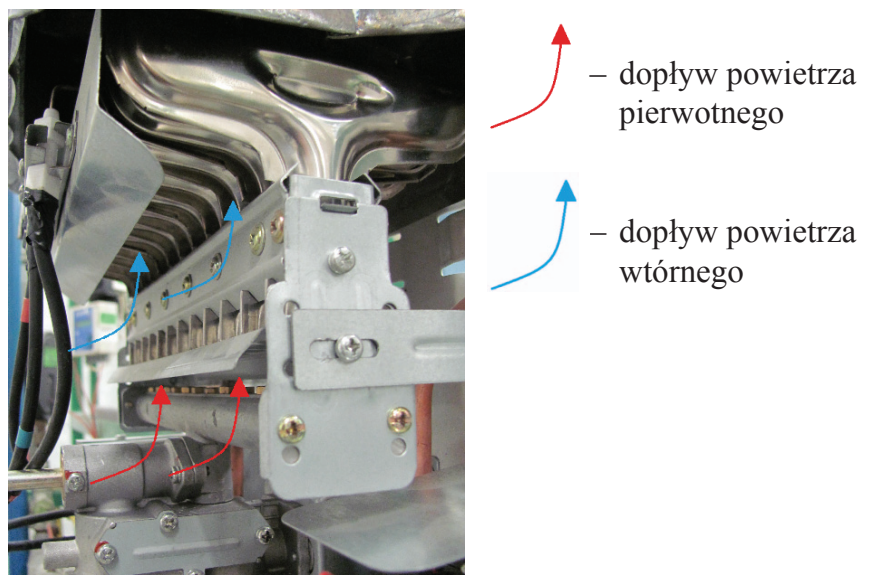

Fot. 1. Widok palnika kinetyczno-dyfuzyjnego badanego grzejnika wody przepływowej
Drugą rozpatrywaną grupę urządzeń stanowią kotły gazowe służące do przygotowania gorącej wody do centralnego ogrzewania. Ze względu na rosnącą popularność urządzeń typu $\mathrm{C}$ jako model do badań wybrano kocioł gazowy z zamkniętą komorą spalania z palnikiem typu pre-mix. Kotty $\mathrm{z}$ tym palnikiem wyposażone są $\mathrm{w}$ wentylator, który oprócz tego, że dostarcza powietrze w ilości potrzebnej do prawidłowego spalania i usuwa spaliny przez system rur koncentrycznych lub rozdzielczych, powoduje także zassanie odpowiedniej ilości gazu, zależnej od jego obrotów. W ten oto sposób odbywa się regulacja obciążenia cieplnego kotła. W tablicy 4 podano wysterowanie obrotów wentylatora dla gazu E i Lw.

Tablica 4. Charakterystyka techniczna badanego kotła gazowego

\begin{tabular}{|l|c|}
\hline Maksymalne obciążenie cieplne & $19,5 \mathrm{~kW}$ \\
\hline Zakres modulacji & $25 \div 100 \%$ \\
\hline Wysterowanie wentylatora: \\
\hline - gaz E & 57 jednostek \\
\hline - gaz Lw & 70 jednostek \\
\hline Typ palnika & $\begin{array}{r}\text { palnik pre-mix, } \\
\text { palnik kinetyczny }\end{array}$ \\
\hline Tryb pracy & modulacja \\
\hline
\end{tabular}

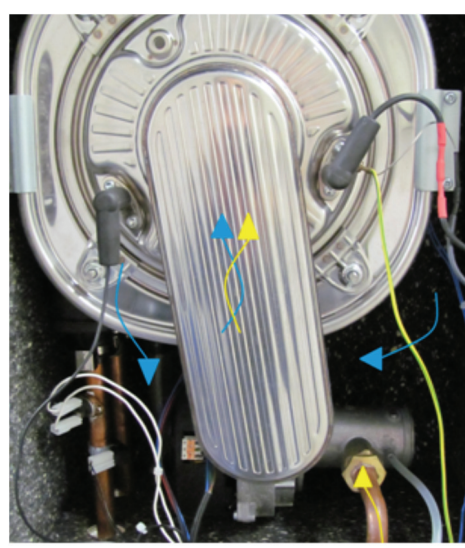

- dopływ gazu z monobloku urządzenia

- powietrze zasysane przez wentylator

- mieszanka gazowopowietrzna

Fot. 2. Widok palnika typu pre-mix (palnik kinetyczny) badanego gazowego kotła centralnego ogrzewania

Producenci tych urządzeń w instrukcji obsługi podają wartość stężenia ditlenku węgla, na jaką należy nastawić kocioł po jego zamontowaniu i wyposażeniu w system rur powietrzno-spalinowych. Urządzenia te działają ze współczynnikiem nadmiaru powietrza potrzebnego do spalania równym około 1,5 i niemal utrzymują ten współczynnik w swoim zakresie modulacji (kocioł posiada zakres modulacji $25 \div 100 \%$ ). W czasie pracy urządzenie zmienia swoje obciążenie cieplne w zależności od zapotrzebowania obiektu na ciepło. Fotografia 2 prezentuje widok badanego palnika kotła gazowego. 
Trzecią grupę urządzeń stanowią gazowe przeponowe nagrzewnice powietrza do zastosowań przemysłowych. Wybrany do badań model to urządzenie typu B wyposażone w kinetyczne palniki inżektorowe $\mathrm{z}$ wentylatorem o stałej mocy zainstalowanym za komorą spalania. Ilość powietrza pobieranego do spalania zależy częściowo od mocy wentylatora i długości przewodów odprowadzających spaliny, a czę-

Tablica 5. Charakterystyka techniczna badanej gazowej nagrzewnicy powietrza

\begin{tabular}{|c|c|}
\hline Znamionowe obciążenie cieplne & $31,4 \mathrm{~kW}$ \\
\hline \multicolumn{2}{|l|}{ Rozmiar dysz gazowych: } \\
\hline- gaz E & $1,85 \mathrm{~mm}$ \\
\hline - gaz Lw & $1,85 \mathrm{~mm}$ \\
\hline Liczba dysz gazowych & 7 sztuk \\
\hline Regulator ciśnienia gazu & zainstalowany \\
\hline \multicolumn{2}{|l|}{ Ciśnienie gazu za regulatorem: } \\
\hline- gaz E & $8 \mathrm{hPa}$ \\
\hline - gaz Lw & $14,5 \mathrm{hPa}$ \\
\hline Typ palnika & $\begin{array}{c}\text { inżektorowy } \\
\text { palnik kinetyczny }\end{array}$ \\
\hline Tryb pracy & włącz-wyłącz \\
\hline
\end{tabular}

ściowo od podciśnienia, które się tworzy, gdy gaz wypływa $z$ dużą prędkością z dyszy gazowej. Tablica 5 prezentuje charakterystykę techniczną badanego modelu.

Fotografia 3 prezentuje widok palnika badanej nagrzewnicy powietrza. Urządzenie pracuje w trybie włącz-wyłącz tylko z obciążeniem znamionowym.

Urządzenia wybrane do badań reprezentują dostępne rozwiązania konstrukcyjne z punktu widzenia różnych grup urządzeń oraz zastosowanych rodzajów palników i sposobów dostarczania powietrza potrzebnego do spalania gazu w tych palnikach.

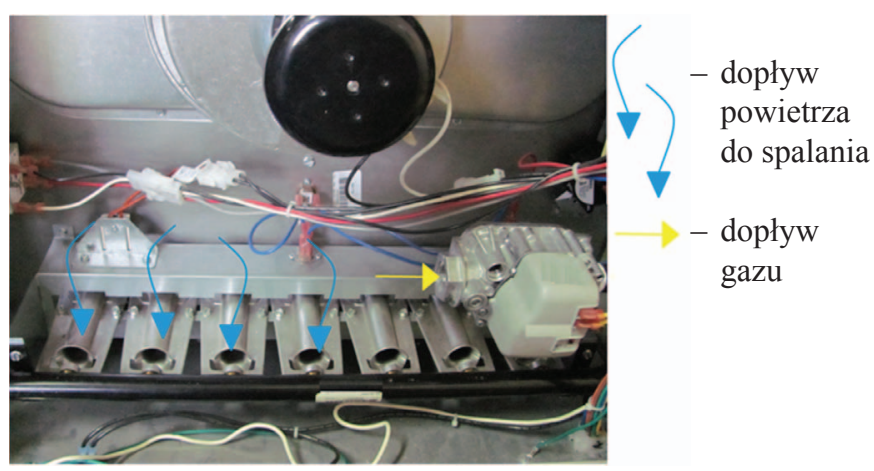

Fot. 3. Widok palnika badanej gazowej nagrzewnicy powietrza

\section{Badanie istotnych parametrów użytkowych wytypowanych urządzeń przy zasilaniu ich opracowanymi mieszankami gazowymi}

\section{Pomiar obciążenia cieplnego}

Pomiarów obciążenia cieplnego dla wszystkich trzech grup urządzeń dokonano z wykorzystaniem gazów G20 i G27 przy nominalnym ciśnieniu zasilania równym $20 \mathrm{hPa}$. Następnie gazy te zastępowano bez zmiany ciśnień gazu przed urządzeniem mieszankami o składzie podanym w tablicy 2 . Weryfikacji znamionowego obciążenia cieplnego (skorygowanego obciążenia cieplnego) dokonano według wzoru (1) $[5,6,7]$ :

$$
\begin{aligned}
Q_{\text {sko }}= & V_{\text {mes }} \times k \times H \times \\
& \times \sqrt{\frac{1013,25+p}{1013,25} \times \frac{p_{a}+p}{1013,25} \times \frac{288}{273+t_{g}} \times \frac{d}{d_{r}}} \times \frac{10000}{36}
\end{aligned}
$$

gdzie:

$Q_{\text {sko }}$ - skorygowane obciążenie cieplne [W],

$V_{\text {mes }}-$ strumień objętości gazu zmierzony w warunkach po$\operatorname{miaru}\left[\mathrm{m}^{3} / \mathrm{h}\right]$,

$H$ - wartość opałowa lub ciepło spalania gazu $\left(15^{\circ} \mathrm{C}\right.$, $1013,25 \mathrm{hPa})\left[\mathrm{MJ} / \mathrm{m}^{3}\right]$,

$k$ - poprawka gazomierza [-],

$p_{a}-$ ciśnienie atmosferyczne $[\mathrm{hPa}]$,

$p$ - ciśnienie zasilania gazem w punkcie pomiaru $[\mathrm{hPa}]$,

$t_{g}$ - temperatura gazu w punkcie pomiaru $\left[{ }^{\circ} \mathrm{C}\right]$, d - względna gęstość gazu w stosunku do suchego powietrza $[-]$,

$d_{r}$ - względna gęstość gazu odniesienia w stosunku do suchego powietrza.

Powyższe równanie jest właściwe, gdy gaz wykorzystywany do badań jest suchy. Jeżeli używa się gazomierza mokrego lub gdy stosowany gaz jest nasycony wilgocią, to wartość $d$ należy zastapić wartością gęstości względnej gazu wilgotnego $d_{h}$, określoną przez równanie (2):

$$
d_{h}=\frac{\left(p_{a}+p-p_{w}\right) \times d+0,622 \times p_{w}}{p_{a}+p}
$$

gdzie:

$d_{h}$ - gęstość względna gazu wilgotnego w stosunku do suchego powietrza,

$d$ - względna gęstość gazu w stosunku do suchego powietrza,

$p_{a}$ - ciśnienie atmosferyczne $[\mathrm{hPa}]$,

$p$ - ciśnienie zasilania gazem $\mathrm{w}$ punkcie pomiaru [hPa],

$p_{w}-$ ciśnienie cząstkowe pary wodnej $[\mathrm{hPa}] \mathrm{w}$ temperaturze $t_{g}$.

Wartość obciążenia skorygowanego informuje, jakie byłoby obciążenie cieplne, gdyby w chwili pomiaru pano- 
wały warunki odniesienia (gaz suchy, $15^{\circ} \mathrm{C}, 1013,25 \mathrm{hPa}$ ). Obciążenie cieplne dla gazowego grzejnika wody przepływowej i kotła gazowego określono według wartości opałowej, zaś dla nagrzewnicy powietrza według ciepła spalania $[5,6,7]$.

\section{Pomiar jakości spalania}

Pomiarów jakości spalania dla wszystkich trzech grup urządzeń dokonano z wykorzystaniem gazów G20 i G27 przy znamionowym obciążeniu cieplnym. Następnie gazy te zastępowano bez zmiany ciśnień gazu przed urządzeniem mieszankami o składzie podanym w tablicy 2 .

Pobieranie próbek spalin przeprowadzono z zastosowaniem tzw. pajączka. Próbki pobierano poprzez zassanie pewnej ilości gazów z przewodu spalinowego każdego $\mathrm{z}$ urządzeń. Sprawdzenie zawartości tlenku węgla w spalinach wykonywano, gdy urządzenia osiągnęły stan równowagi cieplnej. Stężenie objętościowe $\mathrm{CO}$ w suchych i nierozcieńczonych powietrzem spalinach określano wzorem (3) $[5,6,7]$ :

$$
(\mathrm{CO})_{\mathrm{N}}=(\mathrm{CO})_{\mathrm{M}} \times \frac{\left(\mathrm{CO}_{2}\right)_{\mathrm{N}}}{\left(\mathrm{CO}_{2}\right)_{\mathrm{M}}}
$$

gdzie:

$(\mathrm{CO})_{\mathrm{N}}$ - procentowe stężenie objętościowe tlenku węgla w suchych, nierozcieńczonych powietrzem spalinach, $\left(\mathrm{CO}_{2}\right)_{\mathrm{N}}$ - procentowe stężenie objętościowe ditlenku węgla obliczone dla suchych, nierozcieńczonych powietrzem spalin, $(\mathrm{CO})_{\mathrm{M}} \mathrm{i}\left(\mathrm{CO}_{2}\right)_{\mathrm{M}}$ - procentowe stężenia objętościowe tlenku i ditlenku węgla zmierzone w próbkach spalin suchych podczas badania.

\section{Badanie zapłonu, przenoszenia się i stabilności płomienia}

Sprawdzenia zapłonu, przenoszenia się i stabilności płomienia dla wszystkich trzech grup urządzeń dokonano, zasilając urządzenia przewidzianymi w pracy mieszankami pod ciśnieniem nominalnym równym $20 \mathrm{hPa}$. Badania przeprowadzono dla urządzeń znajdujących się w stanie zimnym i w stanie równowagi cieplnej.

\section{Wyniki pomiarów}

\section{Gazowy grzejnik wody przepływowej - pierwsza grupa urządzeń}

W tablicy 6 przedstawiono wyniki pomiarów skorygowanego obciążenia cieplnego dla gazowego grzejnika wody

Tablica 6. Skorygowane obciążenie cieplne - gazowy grzejnik wody przepływowej

\begin{tabular}{|c|c|c|c|}
\hline $\begin{array}{c}\text { Rodzaj } \\
\text { gazu }\end{array}$ & $\begin{array}{c}\text { Skorygowane } \\
\text { obciążenie } \\
\text { cieplne } \\
{[\mathrm{kW}]}\end{array}$ & $\begin{array}{c}\text { Rodzaj } \\
\text { gazu }\end{array}$ & $\begin{array}{c}\text { Skorygowane } \\
\text { obciążenie cieplne } \\
{[\mathrm{kW}]}\end{array}$ \\
\hline $\mathrm{E}$ & 17,9 & $\mathrm{Lw}$ & 17,8 \\
\hline $\mathrm{B}+\mathrm{LNG}_{(\mathrm{E})}$ & 16,3 & $\mathrm{~B}+\mathrm{LNG}_{(\mathrm{Lw})}$ & $\begin{array}{c}\text { Badania przerwano } \\
\text { ze względu na nie- } \\
\text { stabilną pracę pal- } \\
\text { nika, stwarzającą } \\
\text { zagrożenie }\end{array}$ \\
\hline
\end{tabular}

Tablica 7. Jakość spalania - gazowy grzejnik wody przepływowej

\begin{tabular}{|c|c|c|c|}
\hline Rodzaj gazu & $\mathrm{CO}[\mathrm{ppm}]$ & $\mathrm{NO}[\mathrm{ppm}]$ & $\mathrm{NO}_{2}[\mathrm{ppm}]$ \\
\hline $\mathrm{E}$ & 21 & 72 & 32 \\
\hline $\mathrm{B}+\mathrm{LNG}_{(\mathrm{E})}$ & 5 & 44 & 13 \\
\hline $\mathrm{B}+\mathrm{LPG}_{(\mathrm{E})}$ & 5 & 26 & 9 \\
\hline $\mathrm{Lw}$ & 34 & 67 & 27 \\
\hline $\mathrm{B}+\mathrm{LNG}_{(\mathrm{Lw})}$ & \multicolumn{3}{|c|}{$\begin{array}{c}\text { Badania przerwano ze względu na niesta- } \\
\text { bilną pracę palnika, stwarzającą zagrożenie }\end{array}$} \\
\hline $\mathrm{B}+\mathrm{LPG}_{(\mathrm{Lw})}$ & \multicolumn{4}{|c}{}
\end{tabular}

przepływowej przy zasilaniu urządzenia gazami odniesienia i badanymi mieszankami pod ciśnieniem nominalnym równym $20 \mathrm{hPa}$.

Wyniki pomiarów jakości spalania dla gazowego grzejnika wody przepływowej przy zasilaniu urządzenia gazami odniesienia i badanymi mieszankami pod ciśnieniem nominalnym równym $20 \mathrm{hPa}$ ilustruje tablica 7.

Tablica 8. Wyniki sprawdzenia zapłonu, przenoszenia się i stabilności płomienia - gazowy grzejnik wody przepływowej

\begin{tabular}{|c|c|c|c|c|}
\hline $\begin{array}{l}\text { Rodzaj } \\
\text { gazu }\end{array}$ & $\begin{array}{c}\text { Stan } \\
\text { nagrzania } \\
\text { urządzenia }\end{array}$ & $\begin{array}{c}\text { Zapłon } \\
\text { płomienia }\end{array}$ & $\begin{array}{l}\text { Przenoszenie } \\
\text { się płomienia }\end{array}$ & $\begin{array}{l}\text { Stabilność } \\
\text { płomienia }\end{array}$ \\
\hline \multirow{2}{*}{ E } & zimny & WZ & WZ & WZ \\
\hline & gorący & WZ & WZ & WZ \\
\hline \multirow{2}{*}{$\mathrm{B}+\mathrm{LNG}_{(\mathrm{E})}$} & zimny & WZ & WZ & WZ \\
\hline & gorący & WZ & WZ & WZ \\
\hline \multirow{2}{*}{$\mathrm{B}+\mathrm{LPG}_{(\mathrm{E})}$} & zimny & WZ & WZ & WZ \\
\hline & gorący & WZ & WZ & WZ \\
\hline \multirow{2}{*}{ Lw } & zimny & WZ & WZ & WZ \\
\hline & gorący & $\mathrm{WZ}$ & $\mathrm{WZ}$ & $\mathrm{WZ}$ \\
\hline \multirow{2}{*}{$\mathrm{B}+\mathrm{LNG}_{(\mathrm{Lw})}$} & zimny & WZ & WN & WN \\
\hline & gorący & WZ & WN & $\mathbf{W N}$ \\
\hline \multirow{2}{*}{$\mathrm{B}+\mathrm{LPG}_{(\mathrm{Lw})}$} & zimny & WZ & WN & WN \\
\hline & gorący & WZ & WN & WN \\
\hline
\end{tabular}


W tablicy 8 przedstawiono wyniki sprawdzenia zapłonu, przenoszenia się i stabilności płomienia przy zasilaniu gazowego grzejnika wody przepływowej gazami odniesienia i badanymi mieszankami pod ciśnieniem nominalnym równym $20 \mathrm{hPa}$ w stanie zimnym i gorącym.

\section{Gazowy kocioł centralnego ogrzewania - druga grupa urządzeń}

Wyniki pomiarów skorygowanego obciążenia cieplnego dla gazowego kotła centralnego ogrzewania przy zasilaniu urządzenia gazami odniesienia i badanymi mieszankami pod ciśnieniem nominalnym równym $20 \mathrm{hPa}$ przedstawiono w tablicy 9.

W tablicy 10 zamieszczono wyniki pomiarów jakości spalania dla gazowego kotła centralnego ogrzewania przy zasilaniu urządzenia gazami odniesienia i badanymi mieszankami pod ciśnieniem nominalnym równym $20 \mathrm{hPa}$.

Wyniki pomiarów zapłonu, przenoszenia się i stabilności płomienia przy zasilaniu gazowego kotła centralnego ogrzewania gazami odniesienia i badanymi mieszankami pod ciśnieniem nominalnym równym $20 \mathrm{hPa}$ w stanie zimnym i gorącym zestawiono w tablicy 11.

Tablica 9. Skorygowane obciążenie cieplne - gazowy kocioł centralnego ogrzewania

\begin{tabular}{|c|c|c|c|}
\hline $\begin{array}{c}\text { Rodzaj } \\
\text { gazu }\end{array}$ & $\begin{array}{c}\text { Skorygowane } \\
\text { obciążenie } \\
\text { cieplne } \\
{[\mathrm{kW}]}\end{array}$ & $\begin{array}{c}\text { Rodzaj } \\
\text { gazu }\end{array}$ & $\begin{array}{c}\text { Skorygowane } \\
\text { obciążenie cieplne } \\
{[\mathrm{kW}]}\end{array}$ \\
\hline $\mathrm{E}$ & 19,7 & $\mathrm{Lw}$ & 19,4 \\
\hline $\mathrm{B}+\mathrm{LNG}_{(\mathrm{E})}$ & 17,2 & $\mathrm{~B}+\mathrm{LNG}_{(\mathrm{LW})}$ & 18,5 \\
\hline $\mathrm{B}+\mathrm{LPG}_{(\mathrm{E})}$ & 18,3 & $\mathrm{~B}+\mathrm{LPG}_{(\mathrm{Lw})}$ & 19,2 \\
\hline
\end{tabular}

Tablica 10. Jakość spalania - gazowy kocioł centralnego ogrzewania

\begin{tabular}{|c|c|c|c|}
\hline Rodzaj gazu & $\mathrm{CO}[\mathrm{ppm}]$ & $\mathrm{NO}[\mathrm{ppm}]$ & $\mathrm{NO}_{2}[\mathrm{ppm}]$ \\
\hline $\mathrm{E}$ & 71 & 17 & 3 \\
\hline $\mathrm{B}+\mathrm{LNG}_{(\mathrm{E})}$ & 20 & 7 & 2 \\
\hline $\mathrm{B}+\mathrm{LPG}_{(\mathrm{E})}$ & 23 & 7 & 3 \\
\hline $\mathrm{Lw}$ & 75 & 20 & 6 \\
\hline $\mathrm{B}+\mathrm{LNG}_{(\mathrm{Lw})}$ & 47 & 12 & 4 \\
\hline $\mathrm{B}+\mathrm{LPG}_{(\mathrm{Lw})}$ & 43 & 5 & 3 \\
\hline
\end{tabular}

\section{Gazowa nagrzewnica powietrza - trzecia grupa urządzeń}

W tablicy 12 przedstawiono wyniki pomiarów skorygowanego obciążenia cieplnego dla gazowej nagrzewnicy powietrza przy zasilaniu urządzenia gazami odniesienia i badanymi mieszankami pod ciśnieniem nominalnym równym $20 \mathrm{hPa}$.
Tablica 11. Wyniki sprawdzenia zapłonu, przenoszenia się i stabilności płomienia - gazowy kocioł centralnego ogrzewania

\begin{tabular}{|c|c|c|c|c|}
\hline \multirow{2}{*}{$\begin{array}{c}\text { Rodzaj } \\
\text { gazu }\end{array}$} & $\begin{array}{c}\text { Stan } \\
\text { nagrzania } \\
\text { urządzenia }\end{array}$ & $\begin{array}{c}\text { Zapłon } \\
\text { płomienia }\end{array}$ & $\begin{array}{c}\text { Przenoszenie } \\
\text { się płomienia }\end{array}$ & $\begin{array}{c}\text { Stabilność } \\
\text { płomienia }\end{array}$ \\
\hline \multirow{2}{*}{$\mathrm{E}$} & zimny & $\mathrm{WZ}$ & $\mathrm{WZ}$ & $\mathrm{WZ}$ \\
\cline { 2 - 5 } & gorący & $\mathrm{WZ}$ & $\mathrm{WZ}$ & $\mathrm{WZ}$ \\
\hline \multirow{2}{*}{$\mathrm{B}+\mathrm{LNG}_{(\mathrm{E})}$} & zimny & $\mathrm{WZ}$ & $\mathrm{WZ}$ & $\mathrm{WZ}$ \\
\cline { 2 - 5 } & gorący & $\mathrm{WZ}$ & $\mathrm{WZ}$ & $\mathrm{WZ}$ \\
\hline \multirow{2}{*}{$\mathrm{B}+\mathrm{LPG}_{(\mathrm{E})}$} & zimny & $\mathrm{WZ}$ & $\mathrm{WZ}$ & $\mathrm{WZ}$ \\
\cline { 2 - 5 } & gorący & $\mathrm{WZ}$ & $\mathrm{WZ}$ & $\mathrm{WZ}$ \\
\hline \multirow{2}{*}{$\mathrm{LW}^{*} \mathrm{~B}+\mathrm{LNG}_{(\mathrm{Lw})}$} & zimny & $\mathrm{WZ}$ & $\mathrm{WZ}$ & $\mathrm{WZ}$ \\
\cline { 2 - 5 } & gorący & $\mathrm{WZ}$ & $\mathrm{WZ}$ & $\mathrm{WZ}$ \\
\hline \multirow{2}{*}{$\begin{array}{c}\mathrm{B}+ \\
\mathrm{LPG}_{(\mathrm{Lw})}\end{array}$} & gorący & $\mathrm{WZ}$ & $\mathrm{WZ}$ & $\mathrm{WZ}$ \\
\cline { 2 - 5 } & gorący & $\mathrm{WZ}$ & $\mathrm{WZ}$ & $\mathrm{WZ}$ \\
\hline
\end{tabular}

WZ - wynik zgodny, WN - wynik niezgodny.

Tablica 13 ilustruje wyniki pomiarów jakości spalania dla gazowej nagrzewnicy powietrza przy zasilaniu urządzenia gazami odniesienia i badanymi mieszankami pod ciśnieniem nominalnym równym $20 \mathrm{hPa}$.

Tablica 12. Skorygowane obciążenie cieplne - gazowa nagrzewnica powietrza

\begin{tabular}{|c|c|c|c|}
\hline $\begin{array}{c}\text { Rodzaj } \\
\text { gazu }\end{array}$ & $\begin{array}{c}\text { Skorygowane } \\
\text { obciążenie } \\
\text { cieplne } \\
{[\mathrm{kW}]}\end{array}$ & $\begin{array}{c}\text { Rodzaj } \\
\text { gazu }\end{array}$ & $\begin{array}{c}\text { Skorygowane } \\
\text { obciążenie cieplne } \\
{[\mathrm{kW}]}\end{array}$ \\
\hline $\mathrm{E}$ & 31,3 & $\mathrm{Lw}$ & 30,7 \\
\hline $\mathrm{B}+\mathrm{LNG}_{(\mathrm{E})}$ & 26,7 & $\mathrm{~B}+\mathrm{LNG}_{(\mathrm{Lw})}$ & 29,4 \\
\hline $\mathrm{B}+\mathrm{LPG}_{(\mathrm{E})}$ & 28,2 & $\mathrm{~B}+\mathrm{LPG}_{(\mathrm{Lw})}$ & 30,0 \\
\hline
\end{tabular}

Tablica 13. Jakość spalania - gazowa nagrzewnica powietrza

\begin{tabular}{|c|c|c|c|}
\hline Rodzaj gazu & $\mathrm{CO}[\mathrm{ppm}]$ & $\mathrm{NO}[\mathrm{ppm}]$ & $\mathrm{NO}_{2}[\mathrm{ppm}]$ \\
\hline $\mathrm{E}$ & 18 & 73 & 13 \\
\hline $\mathrm{B}+\mathrm{LNG}_{(\mathrm{E})}$ & 22 & 45 & 10 \\
\hline $\mathrm{B}+\mathrm{LPG}_{(\mathrm{E})}$ & 39 & 38 & 11 \\
\hline $\mathrm{Lw}$ & 16 & 70 & 13 \\
\hline $\mathrm{B}+\mathrm{LNG}_{(\mathrm{Lw})}$ & 27 & 52 & 12 \\
\hline $\mathrm{B}+\mathrm{LPG}_{(\mathrm{Lw})}$ & 47 & 43 & 13 \\
\hline
\end{tabular}

W tablicy 14 przedstawiono wyniki pomiarów zapłonu, przenoszenia się i stabilności płomienia przy zasilaniu gazowej nagrzewnicy powietrza gazami odniesienia i badanymi mieszankami pod ciśnieniem nominalnym równym $20 \mathrm{hPa}$ w stanie zimnym i gorącym. 
Tablica 14. Wyniki sprawdzenia zapłonu, przenoszenia się i stabilności płomienia - gazowa nagrzewnica powietrza

\begin{tabular}{|c|c|c|c|c|}
\hline \multirow{2}{*}{ Rodzaj gazu } & $\begin{array}{c}\text { Stan nagrzania } \\
\text { urządzenia }\end{array}$ & $\begin{array}{c}\text { Zapłon } \\
\text { płomienia }\end{array}$ & $\begin{array}{c}\text { Przenoszenie } \\
\text { się płomienia }\end{array}$ & $\begin{array}{c}\text { Stabilność } \\
\text { płomienia }\end{array}$ \\
\hline \multirow{2}{*}{$\mathrm{E}$} & zimny & $\mathrm{WZ}$ & $\mathrm{WZ}$ & $\mathrm{WZ}$ \\
\cline { 2 - 5 } & gorący & $\mathrm{WZ}$ & $\mathrm{WZ}$ & $\mathrm{WZ}$ \\
\hline \multirow{2}{*}{$\mathrm{B}+\mathrm{LNG}_{(\mathrm{E})}$} & zimny & $\mathrm{WZ}$ & $\mathrm{WZ}$ & $\mathrm{WZ}$ \\
\cline { 2 - 5 } & gorący & $\mathrm{WZ}$ & $\mathrm{WZ}$ & $\mathrm{WZ}$ \\
\hline \multirow{2}{*}{$\mathrm{B}+\mathrm{LPG}_{(\mathrm{E})}$} & zimny & $\mathrm{WZ}$ & $\mathrm{WZ}$ & $\mathrm{WZ}$ \\
\cline { 2 - 5 } & gorący & $\mathrm{WZ}$ & $\mathrm{WZ}$ & $\mathrm{WZ}$ \\
\hline \multirow{2}{*}{$\mathrm{LW}^{*} \mathrm{~B}+\mathrm{LNG}_{(\mathrm{Lw})}$} & zimny & $\mathrm{WZ}$ & $\mathrm{WZ}$ & $\mathrm{WZ}$ \\
\cline { 2 - 5 } & gorący & $\mathrm{WZ}$ & $\mathrm{WZ}$ & $\mathrm{WZ}$ \\
\hline \multirow{2}{*}{$\mathrm{B}+\mathrm{LPG}_{(\mathrm{Lw})}$} & gorący & $\mathrm{WZ}$ & $\mathrm{WZ}$ & $\mathrm{WZ}$ \\
\cline { 2 - 5 } & zimny & $\mathrm{WZ}$ & $\mathrm{WZ}$ & $\mathrm{WZ}$ \\
\hline
\end{tabular}

WZ - wynik zgodny, WN - wynik niezgodny.

\section{Podsumowanie}

Wartość obciążenia cieplnego przy zasilaniu badanych urządzeń wytypowanymi w niniejszej pracy mieszankami uległa obniżeniu w stosunku do obciążenia uzyskiwanego dla gazu odniesienia. Wynika to z faktu, że parametry energetyczne przygotowanych mieszanek odpowiadały minimalnym wymaganiom stawianym gazom drugiej rodziny grupy E i Lw.

W praktyce, z punktu widzenia użytkowników gazowych grzejników wody przepływowej, spadek obciążenia znamionowego maksymalnie o około $10 \%$ przy zasilaniu ich mieszankami $\mathrm{B}+\mathrm{LNG}_{(\mathrm{E})}$ i $\mathrm{B}+\mathrm{LPG}_{(\mathrm{E})}$ będzie niezauważalny, gdyż urządzenia te zachowują swoją funkcję użytkową. Zazwyczaj użytkownicy nie wykorzystują pełnej mocy urządzenia i nastawiają pokrętła regulacji obciążenia cieplnego na niższe wartości. Podczas zasilania urządzenia mieszankami $\mathrm{B}+\mathrm{LNG}_{(\mathrm{Lw})}$ i $\mathrm{B}+\mathrm{LPG}_{(\mathrm{Lw})}$ jego palnik pracował niestabilnie. Ze względów bezpieczeństwa badania przerwano.

W przypadku modulacyjnych kotłów centralnego ogrzewania, które działają w oparciu o sterownik z tzw. pogodówką, lub są sterowane czujnikiem temperatury umieszczonym wewnątrz pomieszczenia, użytkownik nie odczuje niewielkiego spadku mocy grzewczej urządzenia. Dla gazowych jednostopniowych nagrzewnic powietrza typu włącz-wyłącz sterowanych temperaturą w obiekcie nieco niższe obciążenie cieplne palnika będzie skutkować jedynie niewielkim wydłużeniem ich czasu pracy. Ewentualne ryzyko niedogrzania obiektów w okresie występowania najniższych temperatur dla użytkowników kotłów cen- tralnego ogrzewania i gazowych nagrzewnic powietrza niweluje to, że urządzenia te zazwyczaj są dobierane z pewnym naddatkiem mocy lub w praktyce ich moc jest znacznie przewymiarowana $\mathrm{w}$ stosunku do rzeczywistego zapotrzebowania obiektu na ciepło.

Jakość spalin z badanych urządzeń przy zasilaniu ich wytypowanymi mieszankami w stosunku do wartości stężeń tlenku węgla i $\mathrm{NO}_{\mathrm{x}}$ uzyskanych na gazach $\mathrm{E}$ i Lw nie uległa pogorszeniu, poza spalinami z gazowego grzejnika wody przepływowej przystosowanego do spalania gazu Lw, a zasilanego mieszankami $\mathrm{B}+\mathrm{LNG}_{(\mathrm{Lw})}$ oraz $\mathrm{B}+\mathrm{LPG}_{(\mathrm{Lw})}$ - badania przerwano ze względu na niestabilną pracę palnika urządzenia. W pozostałych przypadkach palniki urządzeń prawidłowo zapalały się, przenosiły płomień i nie zaobserwowano zjawiska odrywania się płomienia.

Reasumując, badania pokazały, że dla przyjętych rozwiązań konstrukcyjnych gazy oznaczone jako $\mathrm{B}+\mathrm{LNG}_{(\mathrm{E})}$ i $\mathrm{B}+\mathrm{LPG}_{(\mathrm{E})}$ można spalać $\mathrm{w}$ urządzeniach przystosowanych do spalania gazu $\mathrm{E}$ bez potrzeby ich modyfikacji. Mieszanki gazowe oznaczone jako $\mathrm{B}+\mathrm{LNG}_{(\mathrm{Lw})}$ i $\mathrm{B}+\mathrm{LPG}_{(\mathrm{Lw})}$ spalały się prawidłowo $\mathrm{w}$ gazowym kotle centralnego ogrzewania oraz gazowej nagrzewnicy powietrza przystosowanych do gazu Lw. Gazowy grzejnik wody przepływowej ze względu na prostotę konstrukcji (brak regulatora ciśnienia gazu) pracował niestabilnie. Nie wyklucza to jednak w pełni możliwości użytkowania powyższych mieszanek, gdyż istnieją bardziej zaawansowane gazowe grzejniki wody przepływowej - wyposażone w regulator ciśnienia gazu. 
Prosimy cytować jako: Nafta-Gaz 2016, nr 9, s. 747-754, DOI: 10.18668/NG.2016.09.10

Artykuł nadesłano do Redakcji 11.01.2016 r. Zatwierdzono do druku 17.06.2016 r.

Artykuł powstał na podstawie pracy statutowej pt. Wspótspalanie biogazu rolniczego i LNG lub LPG jako alternatywa dla zattaczania biogazu do sieci - praca INiG na zlecenie MNiSW nr decyzji 202014/E-271/S/2015, nr zlecenia: 0052/GU/15/01, nr archiwalny: DK-4100-52/15.

\section{Literatura}

[1] Holewa J., Kukulska-Zając E., Pęgielska M.: Analiza możliwości wprowadzania biogazu do sieci przesyłowej. Nafta-Gaz 2012, nr 8, s. 523-529.

[2] Piskowska-Wasiak J.: Uzdatnianie gazów pochodzenia biologicznego w celu wytwarzania biopaliw i biokomponentów. Nafta-Gaz 2013, nr 3, s. 241-255.

[3] Wojtowicz R.: Wspótspalanie biogazu rolniczego i LNG lub LPG jako alternatywa dla zattaczaniu biogazu do sieci. Praca statutowa $\mathrm{Nr}$ 0013/GU/14, listopad 2014.

\section{Akty prawne i normatywne}

[4] PN-C-04753:2011 Gaz ziemny-Jakość gazu dostarczanego odbiorcom z sieci dystrybucyjnej.

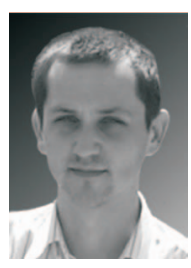

Mgr inż. Tomasz SIUDA

Specjalista inżynieryjno-techniczny w Zakładzie Użytkowania Paliw.

Instytut Nafty i Gazu - Państwowy Instytut Badawczy

ul. Lubicz 25 A

31-503 Kraków

E-mail: tomasz.siuda@inig.pl
[5] PN-EN 1020:2010 Gazowe ogrzewacze powietrza z wymuszona konwekcja do ogrzewania pomieszczeń niemieszkalnych o obciążeniu cieplnym nieprzekraczajacym $300 \mathrm{~kW} z$ wentylatorem wspomagajacym doprowadzenie powietrza do spalania lub odprowadzenie spalin.

[6] PN-EN 26:2007 Gazowe przeptywowe ogrzewacze wody do celów sanitarnych, wyposażone w palniki atmosferyczne.

[7] PN-EN 677:2007 Kotly centralnego ogrzewania opalane gazem-Specjalne wymagania dotyczace kottów kondensacyjnych o znamionowym obciązeniu cieplnym nieprzekraczajacym $70 \mathrm{~kW}$.

\section{OFERTA}

\section{ZAKŁAD INŻYNIERII NAFTOWEJ}

Zakres działania:

- $\quad$ analiza przyczyn oraz badania stopnia uszkodzenia skał zbiornikowych w strefie przyotworowej;

- ocena głębokości infiltracji fazy ciekłej do skał zbiornikowych;

- $\quad$ ocena wpływu roztworów soli i cieczy wiertniczych na skały ilaste strefy przyotworowej

- $\quad$ pomiary parametrów reologicznych cieczy i niektórych ciał stałych w zakresie temperatur od -40 do $200^{\circ} \mathrm{C}$ oraz ciśnień do 150 bar;

- badania oraz dobór cieczy roboczych i solanek do prac związanych z opróbowaniem i rekonstrukcją odwiertów:

- ocena stateczności ścian otworów wiertniczych;

- określanie zdolności produkcyjnej odwiertów;

- $\quad$ symulacja eksploatacji kawernowych podziemnych magazynów gazu w wysadach solnych, z uwzględnieniem konwergencji komór;

- $\quad$ zastosowanie technologii mikrobiologicznych do stymulacji odwiertów oraz usuwania osadów parafinowych w odwiertach i instalacjach napowierzchniowych

- $\quad$ projektowanie zabiegów mikrobiologicznej intensyfikacji wydobycia ropy (MEOR);

- $\quad$ projektowanie zabiegów odcinania dopływu wód złożowych do odwiertów;

- określanie nieredukowalnego nasycenia próbek skały wodą złożową;

- testy zawadniania z użyciem wody, solanki lub $\mathrm{CO}_{2}$

- fotograficzne dokumentowanie rdzeni wiertniczych;

- określanie właściwości mechanicznych oraz sejsmoakustycznych skał w próbach okruchowych;

- $\quad$ analiza zjawisk migracji i ekshalacji gazu ziemnego oraz występowania ciśnień w przestrzeniach międzyrurowych

- modelowanie obiektów złożowych i opracowywanie specjalistycznego oprogramowania z zakresu inżynierii naftowej.

Kierownik: mgr inż. Paweł Budak

Adres: ul. Lubicz 25 A, 31-503 Kraków

Telefon: 126177665

Faks: 124303885

E-mail: pawel.budak@inig.pl

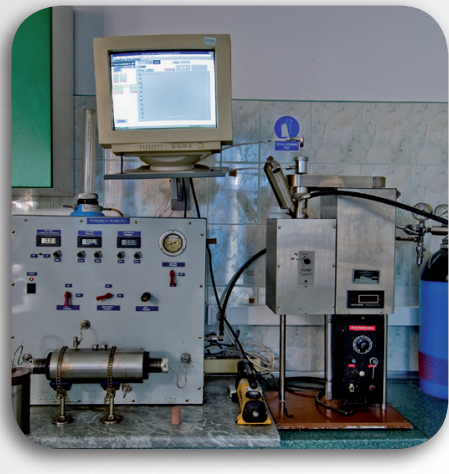

Mgr inż. Robert WOJTOWICZ czych i Grzewczych.

503 Kraków

-mail: robert.wojtowicz@inig.pl 